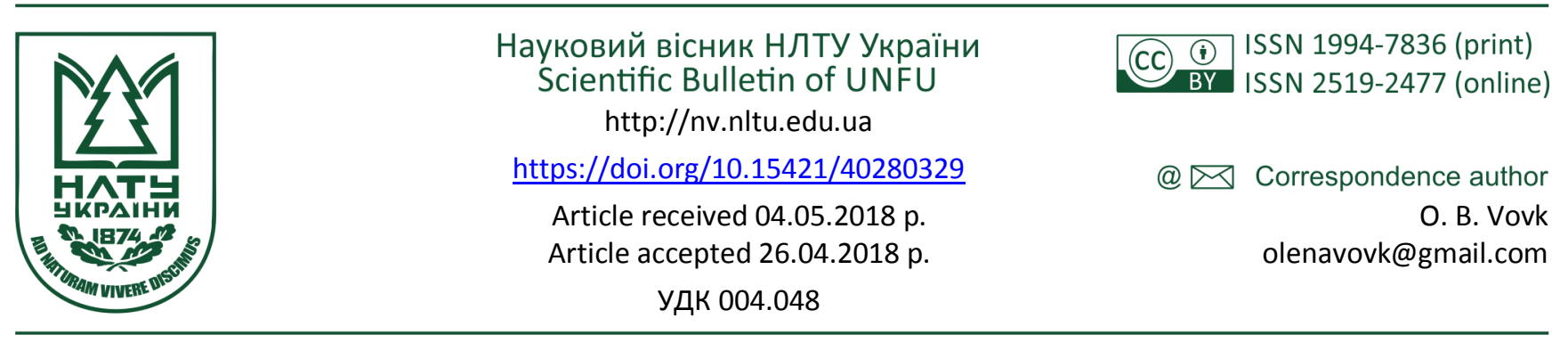

О. Б. Вовк

Національний університет "Львівська політехніка", м. Львів, Україна

\title{
ФОРМУВАННЯ СИСТЕМНОГО ПІДХОДУ ДЛЯ ІНФОРМАЦІЙНОЇ СИСТЕМИ СПОСТЕРЕЖЕННЯ ЗА ВІДХОДАМИ
}

\begin{abstract}
Циркулярна економіка - новий тренд, який має забезпечувати максимальну ефективність кожного процесу в життєвому циклі товару або послуги, та багаторазове використання відходів. Тому організований рециклінг $є$ одним з напрямів. Сьогодні важливо забезпечувати циркуляцію відходів: не викидати відходи, а переробляти їх і знову використовувати. Це важливо з поглядів елементарної гігієни, екології, економіки, виховання відповідних фахівців у закладах вищої технічної освіти. Генерування дедалі більшої кількості різних видів сміття потребує формування організованого рециклінгу, підвищення його ефективності шляхом належного моніторингу автоматичними технічними засобами. Зокрема це передбачає розроблення інформаційної системи з використанням технології ІоТ, яка охоплює засоби ідентифікації, вимірювання та передачі даних, та яка, на думку автора, найкраще підходить для розв'язання задач такого класу. 3 огляду на те, що обсяги побутових відходів згідно з прогнозами зростуть від 1,3 т, вироблених зараз, до 2,2 млрд т до 2025 р., то такі додаткові інструменти будуть необхідні, щоб справлятися з такими великими обсягами сміття. Зроблено спробу з'ясувати, що є системою моніторингу ефективності рециклінгу, які завдання стоять перед нею, які критерії повинні в неї входити.
\end{abstract}

Ключові слова: організований рециклінг; ефективність рециклінгу; моніторинг; циркулярна економіка.

Вступ. Проблема зростання промислових і побутових відходів з кожним днем стає щоразу більш актуальною, причому як для країн, що розвиваються, так і для розвинених країн. Наприклад, $55 \%$ всього європейського сміття у 2014 р. було відправлено на смітник або спалено, що призвело до викиду в атмосферу токсичних і небезпечних речовин, які забруднюють повітря і води Європи, до знищення цінних ресурсів і втрати численних робочих місць у сферах ремонту і повторного використання різного роду продукції.

За прогнозами Організації економічного співробітництва і розвитку (ОЕСР), до 2050 р. наша планета може позбутися двох третин флори і фауни, а збереження територій буде необоротно порушене на площах, за розміром порівняних з Австралією (Rukovodstvo, 2009).

У процесі перероблення твердих побутових відходів (ТПВ) фахівці часто стикаються 3 проблемою формування сукупної інформації з того чи іншого виду ТВП для прийняття рішення щодо подальших дій відносно ТПВ, зокрема використання організованого рециклінгу. Накопичення не переробленого ТПВ призводить до погіршення екології, стану здоров'я людей, економіки.

3 огляду на це, актуальним $\epsilon$ питання щодо підвищення ефективності рециклінгу, створення відповідних критеріїв шляхом належного моніторингу автоматичними технічними засобами, створення відповідних маркувань та технологій перероблення. А отже, дослідження у цій сфері є актуальними.
Аналіз останніх досліджень та публікацій. У світі сьогодні поступово відбувається перегляд традиційної моделі економіки, і дедалі більший резонанс отримує нова парадигма розвитку, заснована на концепції "зеленої" економіки.

Економічну політику "зеленого" зростання офіційно прийнято ОЕСР в 2009 р. як стратегічний напрям розвитку всіх її членів на довгострокову (до 2030 р.) і більш віддалену (до 2050 р.) перспективи. Основною перевагою циркулярної ("зеленої") економіки є те, що вона не тільки зберігає природу, а й забезпечує подальше економічне зростання без підвищення споживання (i збільшення звалищ), а також створюе нові робочі місця (Rukovodstvo, 2009).

У багатьох країнах світу створено нормативно-правову базу в галузі утилізації та повторного використання промислових і побутових відходів.

В Україні минулого року було підписано Закон України "Про відходи" (Zakon Ukrainy, 2017), в якому з 1 січня 2018 р. українці зобов'язані сортувати все сміття за видами матеріалів, а також розділяти його на придатне для повторного використання, для захоронення та небезпечне.

Це повинно заперечити цілий такі переваги:

1) запобігання виділенню метану зі сміттєвих звалищ;

2) урівноваження викидів парникових газів під час виробництва електроенергії з використанням викопного палива;

\section{Інформація про автора:}

Вовк Олена Борисівна, канд. техн. наук, доцент, кафедра систем штучного інтелекту. Email: olenavovk@gmail.com; https://orcid.org/0000-0001-5523-0901

Цитування за ДСту: Вовк О. Б. Формування системного підходу для інформаційної системи спостереження за відходами. Науковий вісник НЛТУ України. 2018, т. 28, № 3. С. 142-146.

Citation APA: Vovk, O. B. (2018). Formation of Systems Approach to Information System of Supervision of Waste. Scientific Bulletin of UNFU, 28(3), 142-146. https://doi.org/10.15421/40280329 
3) регенерацію і повторне використання цінних ресурсів, наприклад металів;

4) виробництво чистої енергії і чистої пари для задоволення базових потреб споживачів в електроенергії;

5) використання меншої площі для виробництва одного мегавата енергії порівняно 3 іншими об'єктами, що виробляють енергію з відновлюваних джерел;

6) надавати доступне джерело екологічно безпечної енергії (порівняно зі сонячною і вітровою енергією);

7) знищення хімічних відходів і руйнування традиційних небезпечних забруднювачів повітря;

8) зниження показників викидів до значень, які набагато нижчі від дозволеного рівня;

9) каталітичне руйнування $\mathrm{NO}_{x}$, діоксинів і фуранів.

Проте, незважаючи на посилену увагу до проблем захисту навколишнього середовища і скорочення відходів, екологічна обстановка в країні залишається досить складною. Система збирання та перероблення сміття в Україні практично не оновлювалася протягом останніх 70 років. Здебільшого сміття ховають на спеціальних полігонах. Збір фільтратів і звалищних газів при цьому не проводять, що створює значну екологічну небезпеку для навколишніх територій (Bobylev et al., 2015). Крім того, в Україні є недопустимо низький рівень перероблення відходів типу "тверді побутові відходи" (ТПВ).

Як зазначено у звіті Міністерства регіонального розвитку, будівництва і житлово-комунального господарства "Стан сфери поводження 3 побутовими відходами в Україні за 2016 рік", торік лише 5,8 \% усього сміття в Україні було утилізовано:

- 2,71\% - спалили;

- 3,09 \% - відправили на перероблення.

"У 2016 році лише у 575-ти населених пунктах впровадили роздільний збір сміття, запрацював один сміттєспалювальний завод і три сміттєспалювальні установки" [3].

Для порівняння: у Швеції переробляється близько 99 \% всіх ТПВ (Stalinskii et al., 2017; Galitcyn, Suslov \& Samchenko, 2014) (рис. 1).

\begin{tabular}{|c|c|c|c|c|}
\hline $\begin{array}{c}\text { Поводження } \\
\text { з побутовими } \\
\text { відходамия }\end{array}$ & $\begin{array}{c}\text { Україна } \\
(2015), \text { дані } \\
\text { Мінрегіону } \\
\text { України, } \\
\text { млн т }\end{array}$ & $\begin{array}{c}\text { Країни ЄС } \\
(2015) \text {, дані } \\
\text { Євростату, } \\
\text { млн т }\end{array}$ & $\begin{array}{c}\text { Швеція } \\
(2015), \text { дані } \\
\text { Свростату, } \\
\text { млн т }\end{array}$ & $\begin{array}{c}\text { Польща } \\
\text { (2015), дан } \\
\text { Євростату, } \\
\text { млн т }\end{array}$ \\
\hline & 9,23 & 241 & 4,377 & 10,863 \\
\hline $\begin{array}{r}\begin{array}{r}\text { Захоронення } \\
\text { видалення }\end{array} \\
\end{array}$ & $\begin{array}{c}8,69 \\
(94,1 \%)\end{array}$ & $\begin{array}{c}61 \\
(25,3 \%)\end{array}$ & $\begin{array}{r}0,035 \\
(0,8 \%)\end{array}$ & $\begin{array}{c}4,808 \\
(44,3 \%)\end{array}$ \\
\hline$z_{2} y^{x}$ & $\begin{array}{c}0,25 \\
(2,7 \%)\end{array}$ & $\begin{array}{c}64 \\
(26,6 \%)\end{array}$ & $\begin{array}{l}2,241 \\
(51,2)\end{array}$ & $\begin{array}{c}1,439 \\
(13,2 \%)\end{array}$ \\
\hline & $\begin{array}{c}0,26 \\
(2,8 \%)\end{array}$ & $\begin{array}{c}69 \\
(28,6 \%)\end{array}$ & $\begin{array}{c}2,101 \\
(48,0 \%)\end{array}$ & $\begin{array}{c}4,616 \\
(42,5 \%)\end{array}$ \\
\hline
\end{tabular}

Pис. 1. Поводження з побутовими відходами в Україні та країнах Євросоюзу

Джерело: матеріали "24 каналу". Дані підготували А. Войціховська, Міжнародна неурядова організація "Екологія. Право. Людина".
Крім того, існує переробка відходів з отриманням енергії. Що це таке? Це екологічно безпечна й ефективна $з$ погляду витрат регенерація енергії.

Переробка відходів, зокрема ТПВ і одержуваного 3 них палива, $\epsilon$ цінним поновлюваним джерелом енергії.

По всьому світу працює велика кількість заводів із перероблення відходів, які успішно довели свою ефективність 3 погляду технологій і охорони навколишнього середовища, зокрема:

1) у Північній Америці працює майже 100 заводів із перероблення відходів;

2) у Європі працює більш ніж 500 заводів;

3) в Азії - 1600 заводів.

Переробка відходів в енергію - це не просто спосіб утилізації сміття. Це спосіб відновлення цінних ресурсів. Переробка відходів в енергію $є$ найважливішою стадією ланцюжка сталого управління відходами та відмінно доповнює собою рециркуляцію (організований рециклінг) відходів.

Принцип роботи заводу з перероблення відходів (або 3 отримання енергії з відходів): побутові та промислові тверді відходи перетворюються в електрику і (або) тепло для промислового перероблення і для систем централізованого теплопостачання - це екологічно безпечний i економічно ефективний спосіб регенерації енергії. Під час цього процесу відходи спалюються за високих температур, а отримане тепло використовують для виробництва пари. Отримана пара приводить в рух турбіну, яка виробляє електрику. Такий спосіб отримання енергії 3 відходів дає змогу відновити цінні ресурси.

На сьогодні можна повторно використовувати 90 \% металів, що містяться в зольному шлаку. А решта шлаку можуть повторно використовувати як дорожній матеріал.

Проте сьогодні проблема накопичення та утилізації ТПВ потребує системного підходу на всіх рівнях, включаючи державний та виробничий. Тому в Україні необхідне створення реально діючих механізмів, що реалізують принципи організованого рециклінгу, що зв'язують промислові підприємства в єдину глобальну промислову мережу, де відходи одного виробництва стають сировиною для іншого.

Мета дослідження - визначити основні завдання моніторингу ефективності рециклінгу в Україні, виявити основні обмеження на шляху його організації, сформувати основні критерії для підвищення ефективності організованого рециклінгу.

Вiдxоди - будь-які речовини, матеріали і предмети, що утворилися у процесі виробництва чи споживання, а також товари (продукція), що повністю або частково втратили свої споживчі властивості й не мають подальшого використання за місцем їх утворення чи виявлення і від яких їх власник позбувається, має намір або повинен позбутися шляхом утилізації чи видалення (Zakon Ukrainy, 2017).

Моніторинг (від лат. monitor - застережливий) - метод дослідження об'єкта, що передбачає його відстеження і контролювання його діяльності (функціонування) для прогнозування останньої (Zakon Ukrainy, 2017).

Пак Хе Сун (а також Г.В. Терешкин ) пропонують розуміти під моніторингом систематичну діяльність, спрямовану на відстеження процесу і результатів програми на підставі планомірного вимірювання значень низки показників (критеріїв). При цьому зазначають, 
що в рамках моніторингу важливо не просто відстежувати процес здійснення тієї чи іншої діяльності, а акцентувати увагу саме на аналізі прогресу з погляду досягнутих результатів (Pak Khe Sun \& Tereshkin, 2009).

У межах рекомендацій ООН пропонують єдину категорію Monitoring and Evaluation (M \& E) (моніторинг і оцінка).

Нижче подано основні завдання M \& E:

- визначити чи відповідають намічені результати програми запланованим;

- які коригувальні заходи необхідні, щоб забезпечити отримання намічених результатів;

- чи робить реалізація програми позитивний внесок у суспільний розвиток (Galitcyn, Suslov \& Samchenko, 2014).

Система організованого рециклінгу, запроваджена 3 кінця XX ст. в розвинених країнах, поступово починає впроваджуватись і в нашій країні. Для досягнення тих цілей, які на неї покладаються, ця система повинна відповідати вимогам економічної, екологічної та соціальної ефективності.

Механізм формування організованого рециклінгу, крім іншого, передбачає створення інтерактивної інформаційної системи на базі сучасних інформаційних технологій, яка, зокрема, забезпечить виявлення і ліквідацію несанкціонованих звалищ сміття на підставі повідомлень громадян, громадських організацій, а надалі автоматичного моніторингу автономними технічними засобами, що дасть змогу оцінити ефективність рециклінгу відходів із позиції різних типів ефективності.

Для ефективного моніторингу в цій інформаційній системі потрібно використати технологію ІоТ, що дасть змогу:

Таблиця. Основні принципи формування системи критеріїв моніторингу ефективності рециклінгу

\begin{tabular}{|c|l|}
\hline Принцип & \multicolumn{1}{|c|}{ Зміст принципу } \\
\hline Системність & $\begin{array}{l}\text { Критерії не повинні "перекривати" один одного та під час представлення інформації бути порівняльни- } \\
\text { ми один з одним }\end{array}$ \\
\hline Однозначність & $\begin{array}{l}\text { Визначення критеріїв і способи їх обчислення повинні грунтуватися на єдиній методології (це збіль- } \\
\text { шує іх цінність, оскільки: по-перше, дає змогу зіставляти їх між собою; по-друге, забезпечує однакове } \\
\text { розуміння їх всіма споживачами) }\end{array}$ \\
\hline Надійність & Дані, необхідні для критеріїв, повинні бути надійними протягом встановленого часу \\
\hline Достовірність & $\begin{array}{l}\text { спосіб збирання та опрацювання вихідної інформації повинен передбачати можливість перевірки точ- } \\
\text { ності отриманих даних }\end{array}$ \\
\hline Інформативність & $\begin{array}{l}\text { Критерії повинні давати підстави не тільки для кількісної, але і якісної характеристики явища або про- } \\
\text { цесу, тому вони повинні бути як первинними, так і притаманними, тобто наведеними в базових показ- } \\
\text { никах }\end{array}$ \\
\hline Комплексність & Будь-який об'єкт є цілісною системою, тому критерії повинні охоплювати всі сфери діяльності об'єкта \\
\hline Порівнянність & Забезпечення порівнянності критеріїв за окремі періоди \\
\hline Сфокусованість & Обмеженість їх множини \\
\hline Чутливість & Критерії повинні чітко реагувати на зміни, які відбуватимуться \\
\hline Доступність & Інформація для визначення критеріїв повинна бути доступною для збирання \\
\hline *економічність & $\begin{array}{l}\text { Отримання даних потрібно здійснювати з мінімально можливими витратами, щоб не допустити пере-- } \\
\text { вищення вартості засобів досягнення цілей над сумарними вигодами від їх виконання }\end{array}$ \\
\hline
\end{tabular}

Далі, відповідно до теми дослідження, розглянемо перелік показників, які використовують під час оцінювання ефективності рециклінгу.

Перш ніж перейти безпосередньо до існуючих у сучасній зарубіжній та вітчизняній науці та практиці систем критеріїв, необхідно зауважити, що в рамках нової парадигми розвитку, заснованій на принципах "зеленої" економіки, традиційні макроекономічні показники, а також показники на мікрорівні й на рівні регіону повинні бути скориговані.

Часто за значним зростанням цих показників ховається вкрай нераціональне використання природних ресурсів, висока ресурсовитратність на виробництві, знищення природи, погіршення екологічних показників.
1) автоматично визначати наповнюваність об'єктів ТПВ;

2) визначати, за допомогою технологій машинного зору, до якого типу належать ті чи інші відходи;

3) кількість відходів, тип відходів за кожним з осередків (районів);

4) прогнозувати кількість відходів (у часовому чи кількісному вимірі).

Це означає, що потрібно створити системний підхід, який включатиме: гу;

2) загальну схему моніторингу ТПВ;

3) організований рециклінг.

Для моніторингу та оцінки досліджуваного явища накопичення ТПВ та процесу моніторингу за цим явищем можна використовувати певні показники (інакше критерії), тобто своєрідні ознаки змін на шляху до покращення ситуації. Іншими словами, критерій повинен вимірювати досягнення, відображати зміни, викликані досліджуваним процесом або явищем.

Ефективну систему критеріїв моніторингу можна побудувати лише в умовах ретельного опрацювання логіки проекту, під час коректного формулювання його цілей і завдань.

Крім того, система критеріїв повинна відповідати певним принципам для досягнення високої ефективності організованого рециклінгу шляхом належного моніторингу автоматичними технічними засобами (табл.). Принципи мають 10 технічних критеріїв та один економічний. Розташовані технічні критерії в порядку зменшення важливості.
1) системи критеріїв моніторингу ефективності рециклін-

Щоб уникнути цього, в останні роки світова спільнота вводить штучні показники, які враховують зокрема й екологічні вимоги. До подібних показників (у порядку важливості) належать:

1) показник гуманітарного розвитку;

2) показник фізичного впливу людини на навколишнє середовище;

3) показник сталого економічного добробуту.

Також існують об'ємні макроекономічні показники, аналогічні використовуваним офіційною статистикою ВВП і ВНП, але враховують вартість екологічних складових (ресурсно-скорегований ВВП, екологічно-скоригований ВВП або "зелений" ВВП, показник впливу на навколишнє середовище та ін.). 
Для оцінки екологічного стану території, ефективності природоохоронних витрат, величини екологічного збитку і втрат використовують загальні та спеціальні показники, зокрема показник вартості екологічного збитку (Abramov \& Kusraeva, 2009).
Отже, показники екологічного моніторингу досить повно розроблені, що, на жаль, не можна сказати про критерії у сфері перероблення та утилізації відходів.

Узагальнену схему моніторингу ТПВ та організований рециклінг представлено на рис. 2.

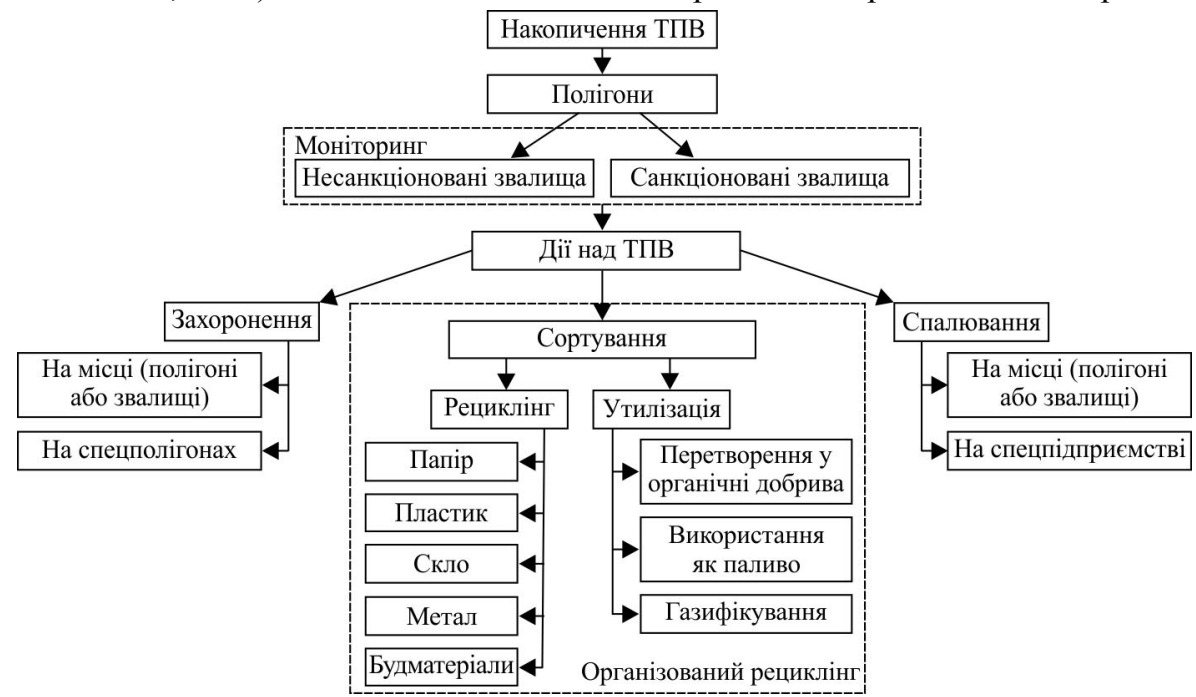

Рис. 2. Узагальнена схема моніторингу ТПВ та організований рециклінг

Разом із тим, необхідність розроблення критеріїв, що дають змогу визначити ефективність організованого рециклінгу, визнано на міжнародному рівні, зокрема на саміті "G 8".

Як подібний інтегральний показник пропонують використовувати інтегральний показник ефективності рециклінгу, що охоплює (у порядку значущості):

1) показник екологічної значущості рециклінгу;

2) показник відносного об'єму передбачуваного рециклінгу;

3) показник економічної ефективності рециклінгу.

Межі вимірювання становлять [0,001-1,0]. При чому, чим більше значення, тим ефективнішим для суспільства $є$ процес рециклінгу (Abramov \& Kusraeva, 2009).

Під час створення системи інтегральних показників ефективного організованого рециклінгу потрібно враховувати, що існує кілька форм утилізації відходів (див. рис. 2), які відрізняються:

1) кількістю стадій, які відходи проходять до того, як їх використають повторно: так званий прямий рециклінг (повторне застосування відразу за прямим призначенням);

2) регенерація (повернення відходів у цикл виробництва після підготовки);

3) рекуперація (витяг із відходів корисних компонентів для їх повторного застосування).

Таким чином, статистика у сфері утилізації відходів повинна враховувати насамперед екологічний аспект проблеми. Тому показники утилізації відходів повинні окремо оцінювати кожну форму утилізації.

Оскільки створення індустрії рециклінгу переслідує більш масштабні цілі, ніж просто констатація статистичних фактів, тому моніторинг ефективності рециклінгу повинен враховувати не тільки екологічні, але й економічні аспекти.

Відповідно до цього, цікавим є підхід, за яким, розглядають класифікацію організованого рециклінгу в неоіндустріальній економіці. У цій ситуації пропонують оцінювати ефективність рециклінгу з позиції впливу таких ефектів:

1) ресурсозберігаючого;
2) екологічного;

3) економічного;

4) науково-технічного;

5) соціального.

При цьому варто зауважити, прямі ефекти (ресурсозберігаючий і екологічний) порівняно легко вимірюються в межах чинної системи статистичного обліку шляхом ланцюгового порівняння відносних показників, що співвідносять вартісну оцінку досягнутої економії ресурсів і ліквідованого екологічного збитку з наведеними витратами.

Непрямі ефекти (економічний, науково-технічний, соціальний) притаманні організованому рециклінгу, як і будь-якій іншій системній інновації, і досить важко вимірюються з різних причин:

1) відсутність необхідної деталізації в системі статистичного обліку;

2) складність взаємодії і взаємозв'язків реципієнтів, які отримують і передають ефекти;

3) різноспрямованість впливу непрямих ефектів в умовах суперечливих інтересів реципієнтів;

4) дія синергетичних ефектів (синергія (від грец. $\Sigma v v \varepsilon \rho \gamma i ́ \alpha-$ співпраця, сприяння, допомога, співучасть,

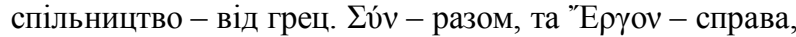
праця, робота, (взаємо) дія) - підсилює ефект взаємодії двох або більше чинників, що характеризується тим, що спільна дія цих чинників істотно перевершує просту суму дій кожного із зазначених чинників. Наприклад: знання і зусилля кількох людей можуть організовуватися так, що вони взаємно посилюються), інші причини.

Однак ігнорування непрямих ефектів під час оцінювання ефективності організованого рециклінгу в дослідженні його впливу на визначену територію може істотно спотворити реальний стан справ.

Висновки. У сучасних умовах формування циркулярної економіки стає для нашої країни актуальним завданням, оскільки їі рішення дасть змогу знизити напруження в екологічній сфері за допомогою скорочення сміттєвих полігонів і звалищ, також буде отримано економічний ефект завдяки застосуванню технологій ре- 
сурсозбереження та соціальний ефект від створення нових робочих місць у сфері утилізації відходів.

Однак система утилізації відходів тільки створюється, тому важливо визначити основні орієнтири для іï розвитку. 3 огляду на це $\epsilon$ актуальним подальше дослідження механізму моніторингу ефективності рециклінгу, оскільки ефективність управління обумовлена наявністю, повнотою і достовірністю даних про стан соціально-економічної системи, а також своєчасністю отримання цих даних.

Для вирішення цього завдання використано системний і критеріальний підходи, а також загальнонаукові методи дослідження. Отже, переважають екологічні показники як у системі державного управління, так і в наукових дослідженнях, а також існують певні проблеми в інформаційному забезпеченні моніторингу. Ці критерії можуть бути включені як цільові у програми щодо поводження з відходами.

Зроблено висновок про необхідність більш повного врахування соціальних, економічних і науково-технічних критеріїв, що дають змогу комплексно оцінити ефективність системи утилізації відходів на будь-якому рівні (державному чи регіональному).

\section{Перелік використаних джерел}

Abramov, A. V., \& Kusraeva, O. S. (2009). Ob effektivnosti retciklinga. Retcikling otkhodov, 5(23), 2-4. [In Russian]

Bobylev, S. N., Vishniakova, V. S., Komarova, I. I., Shevchuk, A. V. (Ed.), et al. (2015). "Zelenaia" ekonomika. Novaia paradigma razvitiia strany. Moscow: SOPS. [In Russian]

Galitcyn, V. K., Suslov, O. P., \& Samchenko, N. K. (2014). Model mekhanizma monitoringa. Nauchnyi institut globalnoi i regionalnoi ekonomiki, 4, 109-111. [In Russian]

Pak Khe Sun, \& Tereshkin, G. V. (2009). Razvitie malogo predprinimatelstva kak kriterii otcenki deiatelnosti organov MSU. Vlast i upravlenie na Vostoke Rossii, 4. [In Russian]

Rukovodstvo po planirovaniiu, monitoringu i otcenke rezultatov razvitiia. (2009). Programma razvitiia Organizatcii Ob'edinennykh Natcii. Moscow. 225 p. [In Russian]

Stalinskii, D. V., Ryzhavskii, A. Z., Rudiuk, A. S., \& Zimogliad, A. V. (2017). Strategiia ratcionalnoi utilizatcii TKO. Tverdye bytovye otkhody, 8, 44-47. [In Russian]

Zakon Ukrainy (2017). Pro vidkhody. Retrieved from: http://zakon2.rada.gov.ua/laws/show/187/98-вp.

СИСТЕМЫ НАБЛЮДЕНИЯ ЗА ОТХОДАМИ

Циркулярная экономика - тренд, который требует обеспечивать максимальную эффективность каждого процесса в жизненном цикле товара или услуги, и многократное использование отходов. Организованный рециклинг является одним из ее приоритетных направлений. Сегодня важно обеспечивать циркуляцию отходов: не выбрасывать отходы, а перерабатывать их и снова использовать. Это важно и с точки зрения элементарной гигиены, и с точки зрения экологии, и с точки зрения экономики, и с точки зрения воспитания соответствующих специалистов. Выработка все большего количества различных видов мусора требует создания организованного рециклинга, повышения его эффективности путем надлежащего мониторинга автоматическими техническими средствами. В частности, это предусматривает разработку информационной системы с использованием технологии ІоТ, которая включает в себя средства идентификации, измерения и передачи данных, и которая, по мнению автора, лучше всего подходит для решения задач такого класса. Учитывая, что объемы отходов согласно прогнозам вырастут с 1,3 т, произведенных сейчас, до 2,2 млрд т к 2025 г., такие инструменты будут крайне необходимы, чтобы справляться с такими большими объемами мусора. Сделана попытка выяснить, что собой представляет система мониторинга эффективности рециклинга, какие задачи стоят перед ней, какие критерии должны в нее входить.

Ключевые слова: организованный рециклинг; эффективность рециклинга; мониторинг; циркулярная экономика.

\section{O.B. Vovk \\ Lviv Polytechnic National University, Lviv, Ukraine}

\section{FORMATION OF SYSTEMS APPROACH TO INFORMATION SYSTEM OF SUPERVISION OF WASTE}

A circular economy is a new trend that requires the maximum efficiency of each process in the life cycle of a product or service and the repeated use of waste. Therefore, organized recycling is one of the priority areas. Today it is important to ensure the circulation of waste: do not dispose of waste, but recycle of it and reuse it. This is important both from the point of view of elementary hygiene, and from the point of view of ecology both from the point of view of the economy and from the point of view of training relevant specialists in higher technical educational institutions. The creation of an increasing number of different types of garbage requires the formation of organized recycling, increasing its efficiency through proper monitoring by automatic technical means. In particular, this is due to the development of an information system using IoT technology, which includes means of identification, measurement and transmission of data and which, in the author's opinion, are best suited for solving problems of this class. Protecting the environment requires a multifaceted solution, but IoT already now offers unique opportunities for addressing such issues as: water and air pollution, the formation of huge dumps with waste. Sensor devices connected to a common network can now closely monitor the state of the environment of our cities, collecting information about sewerage, air quality and garbage. Outside the city, the same sensor network can monitor landfills and landfills with garbage. Considering that the volume of household waste is projected to grow from 1.3 tons currently produced to 2.2 billion tons by 2025 , such additional tools will be essential to combat such large amounts of debris. Many environmental trends are so complex that they are difficult to comprehend, but data collection is the first step towards understanding and ultimately to developing solutions to reduce the negative impact of human activities on the environment. This article attempts to find out what the system of monitoring the effectiveness of recycling is, what tasks are before it, what criteria should be included in it.

Keywords: organized recycling, recycling efficiency, monitoring, circular economy. 